\title{
Membrane Progesterone Receptors: Evidence for Neuroprotective, Neurosteroid Signaling and Neuroendocrine Functions in Neuronal Cells
}

\author{
Peter Thomas Yefei Pang \\ The University of Texas at Austin Marine Science Institute, Port Aransas, Tex., USA
}

\section{Key Words}

Membrane progesterone receptors • Neuroprotection •

Neurosteroid signaling $\cdot$ Neuroendocrine functions •

Allopregnanolone actions $\cdot$ GT1-7 cells $\cdot$ Sphingolipid

signaling $\cdot$ Antiapoptosis

\begin{abstract}
Membrane progesterone receptors (mPRs) are novel G protein-coupled receptors belonging to the progestin and adipoQ receptor family (PAQR) that mediate a variety of rapid cell surface-initiated progesterone actions in the reproductive system involving activation of intracellular signaling pathways (i.e. nonclassical actions). The mPRs are highly expressed in the brain, but research on their neural functions has only been conducted in a single neuronal cell line, GT17 cells, which have negligible nuclear progesterone receptor (PR) expression. GT1-7 cells express $m P R \alpha$ and $m P R \beta$ on their plasma membranes which is associated with the presence of high-affinity, specific $\left[{ }^{3} \mathrm{H}\right]$-progesterone receptor binding. The neurosteroid, allopregnanolone, is an effective ligand for recombinant $\mathrm{mPR} \alpha$ with a relative binding affinity of $7.6 \%$ that of progesterone. Allopregnanolone acts as a potent mPR agonist on GT1-7 cells, mimicking the progesterone-induced decrease in CAMP accumulation and its antiapoptotic actions at low nanomolar concentrations. The decrease in cAMP levels is associated with rapid proges-
\end{abstract}

terone-induced downregulation of $\mathrm{GnRH}$ pulsatile secretion from perifused GT1-7 cells. The recent suggestion that mPRs are alkaline ceramidases and mediate sphingolipid signaling is not supported by empirical evidence that TNF $\alpha$ does not bind to mPRs overexpressed in human cells and that exogenous sphingomyelinase is ineffective in mimicking progestin actions through mPRs to induce meiotic maturation of fish oocytes. Taken together, these recent studies indicate that mPRs mediate neuroprotective effects of progesterone and allopregnanolone and are also the likely intermediaries in progesterone-induced inhibition of pulsatile $\mathrm{GnRH}$ secretion in GT1-7 cells.

Copyright $\odot 2012$ S. Karger AG, Basel

\section{Introduction}

The central role of two intracellular ligand-activated transcription factors, progesterone receptors PR-A and $\mathrm{PR}-\mathrm{B}$, in mediating progesterone's regulation of diverse female vertebrate reproductive functions through altering gene transcription has been unequivocally demonstrated using PR-selective ligands and PR knockout (PRKO) mice [1]. However, many of progesterone's actions are too rapid to be readily explained by a genomic mechanism which typically occurs over a time scale of hours, and it is now widely appreciated that progesterone,

\section{KARGER}

Fax +4161306 1234

E-Mail karger@karger.ch

www.karger.com
(C) 2012 S. Karger AG, Basel

$0028-3835 / 12 / 0962-0162 \$ 38.00 / 0$

Accessible online at:

www.karger.com/nen
Peter Thomas

UT Marine Science Institute

750 Channel View Drive

Port Aransas, TX 78373 (USA)

Tel. +1 361749 6768, E-Mail peter.thomas@utexas.edu 
like other steroid hormones, can also exert rapid cell surface-initiated actions within minutes through activation of membrane receptors and their associated intracellular signaling pathways [2-5]. For example, alternative (i.e. nonclassical) progesterone actions on sperm motility, oocyte meiotic maturation, granulosa cell apoptosis, immunosuppression of T cells, breast and ovarian cancer cells, $\mathrm{GnRH}$ secretion, and reproductive behaviors have been identified and the receptors mediating many of these effects have been biochemically characterized [6-16]. Although some of these alternative progesterone actions are nongenomic, others may ultimately lead to altered gene transcription through activation of second messengers such as MAP kinases and through alteration of PR transactivation through effects on coactivators such as SRC2 [17].

The identities of the receptors mediating many of these nonclassical progesterone actions remain unclear $[5,18]$. Activation of PRs located in the cytoplasmic compartment can mediate nonclassical progesterone signaling through an interaction with Src kinase [19], but other receptor mechanisms must be invoked to explain the cell surface-initiated progesterone actions identified in many target tissues. Although progesterone and its metabolite, allopregnanolone, have been shown to induce rapid effects in neural tissues through modulation $\mathrm{GABA}_{\mathrm{A}}$ receptor activity [20,21], rapid progesterone actions in nonneural tissues, which lack $\mathrm{GABA}_{\mathrm{A}}$ receptors, must involve alternative receptor mechanisms. There is substantial evidence that a putative membrane receptor, progesterone membrane receptor component 1 (PGMRC1), is a component of nonclassical signaling by progesterone and other hormones [22-24], but its exact role is uncertain and clear evidence that it functions as a specific progesterone receptor is lacking $[22,25,26]$. In contrast, extensive evidence has been obtained by different research groups that wild-type membrane progesterone receptors (mPRs) in a wide range of vertebrate cells as well as recombinant proteins expressed in prokaryotic and eukaryotic systems display high-affinity, specific, displaceable and limited capacity progestin binding characteristic of steroid membrane receptors [5, 15, 25, 27-33]. The $\mathrm{mPRs}$ are typically localized on the cell surface and are widely distributed throughout neural, reproductive and nonreproductive vertebrate tissues and are therefore good candidates for the membrane receptors mediating many of these nonclassical cell surface-initiated progesterone actions [27,34-37]. The mPRs were discovered and first characterized in fish ovaries [15], and three isoforms, $\operatorname{mPR} \alpha, \operatorname{mPR} \beta$, and $\operatorname{mPR} \gamma$, were subsequently identified in humans and other vertebrates [27]. The mPRs are 7-transmembrane proteins and activate $\mathrm{G}$ proteins; however, they do not belong to the $G$ protein-coupled receptor superfamily, but are instead members of the progestin and adipoQ receptor (PAQR) family $[28,34]$. The characteristics and functions of mPRs have been discussed extensively in several recent publications [5, 38-40].

In this short review, potential functions of mPRs in neural tissues will be briefly discussed. New data suggesting that progesterone and the neurosteroid allopregnanolone exert protective effects on mouse neuronal GT1-7 cells through $\mathrm{mPRs}$ are discussed as well as recent evidence obtained with this cell line for the involvement of $\mathrm{mPRs}$ in progesterone downregulation of $\mathrm{GnRH}$ pulsatile secretion. The mPRs have recently been proposed to function as alkaline ceramidases based on the results of bioinformatic analyses and investigations of their functions in heterologous yeast systems [40], but the involvement of mPRs in sphingolipid signaling in vertebrate cells has not been reported. Therefore, new data on potential interactions of $\mathrm{TNF} \alpha$ with $\mathrm{mPR} \alpha, \operatorname{mPR} \beta$, and $\mathrm{mPR} \gamma$ overexpressed in human breast cancer cells and on the ability of exogenous sphingomyelinase to mimic progestin induction of meiotic maturation of fish oocytes through mPRs are also discussed.

\section{Role of mPRs in the Antiapoptotic Actions of Progestins in Reproductive Tissues}

Progesterone exerts a physiologically important function in the ovary to inhibit apoptosis of granulosa cells. However, the mechanism of progesterone's antiapoptotic action is unclear because it does not involve activation of the nuclear PR in several cell models [13,41, 42], but instead is initiated at the cell surface which suggests it is mediated through mPRs $[43,44]$. Both PGRMC1 and mPRs have been implicated in these antiapoptotic actions of progestins on granulosa cells [13, 45]. PGRMC1 forms a complex with plasminogen activator inhibitor RNA binding protein (PAIRBP-1) and both of these proteins are localized on the plasma membranes of spontaneously immortalized granulosa cells (SIGCs) $[13,46]$. Treatment with either the siRNA or an N-terminal antibody to PGRMC1 blocked the antiapoptotic actions of progesterone on SIGCs, suggesting involvement of PGRMC1 in this progesterone action [47]. Interestingly, progesterone at high concentrations $(1 \mu \mathrm{M})$ inhibits the expression of the proapoptotic gene $\mathrm{BAD}$ and increases the expression of the antiapoptotic BCL2 family member, BCL2A1D, 
through PGRMC1 in SIGCs [48]. Decreased cell death and antiapoptotic actions of progestins have also been shown to be mediated through mPRs in granulosa and breast cancer cells $[12,45]$. The $\mathrm{mPR} \alpha$ protein is localized on the plasma membranes of teleost granulosa cells and on nuclear PR-negative human breast cancer cells. The demonstration that a specific $\mathrm{mPR}$ agonist, Org OD 02-0 [49], mimics the protective effects of progestin hormones on serum starvation-induced cell death and apoptosis in both granulosa and breast cancer cells indicates mPRs are intermediaries in progestin-induced cell survival. This protective role of $\mathrm{mPR} \alpha$ has been confirmed in both cell types by knockdown studies which show that decreased $\mathrm{mPR} \alpha$ protein expression after treatment with $\mathrm{mPR} \alpha$ siRNA is associated with decreased $\left[{ }^{3} \mathrm{H}\right]$-progesterone binding and a loss of the antiapoptotic actions of progestins $[12,45]$. The finding that progestins activate MAP kinase and Akt through mPRs in both cell types $[12,45]$ is consistent with mPR's antiapoptotic functions because both MAP kinase and Akt are involved in inhibition of cell death and apoptosis [50]. MAP kinase upregulates antiapoptotic members of the BACL2 family and inhibits BAD [51, 52], which is also inhibited by Akt [53]. Inhibition of apoptosis in breast cancer cells by treatment with the mPR-specific ligand, Org OD 02-0, was also accompanied by an increase in mitochondrial membrane potential which has been shown to correlate with increased cell survival. However, caspase 3 activity was unaltered through $\mathrm{mPRs}$ after treatment with Org OD 02-0 [12]. Similarly, caspase gene expression was not altered through PGRMC1 in SIGCs [48]. Thus, progestins appear to exert their antiapoptotic actions through mPRs and PGRMC1 by similar mechanisms which do not involve activation of caspases.

\section{Potential Role of mPRs in the Antiapoptotic Effects of Allopregnanolone in the Brain}

There is extensive evidence that progesterone also exerts a variety of protective effects in the brain, including inhibition of apoptosis [54]. Many of these progesterone effects are mediated through its metabolite, allopregnanolone, a neurosteroid synthesized in the central and peripheral nervous systems [54-56]. Allopregnanolone accumulates during the diurnal cycle and during pregnancy in mammals: mouse brain concentrations increasing up to $35 \mathrm{nM}$ during the scotophase and plasma concentrations in women reaching $100 \mathrm{nM}$ during the third trimester of pregnancy [55]. Allopregnanolone does not activate nuclear PRs and is widely believed to be devoid of direct hormonal action through steroid receptors $[54,56$, 57]. Instead allopregnanolone is thought to exert its antiapoptotic actions in the brain by binding to $\mathrm{GABA}_{\mathrm{A}}$ receptors, causing their allosteric modulation and an increase in their neuronal cell inhibitory activity, as well as by allosteric modulation of $N$-methyl-D-aspartic acid (NMDA) receptors, reducing their NMDA-induced excitotoxicity by a noncompetitive mechanism, and also potentially through activation of pregnane X-dependent pathways [54]. However, the results of recent ligand-binding specificity studies with recombinant human $\mathrm{mPR} \alpha$ challenge the prevailing view that allopregnanolone does not activate steroid hormone receptors. Allopregnanolone was found to have a relatively high binding affinity, $7.6 \%$ that of progesterone, for human $\mathrm{mPR} \alpha$ overexpressed in MDA-MB 231 human breast cancer cells [28, 49].

The finding that allopregnanolone, which has been shown to mediate antiapoptotic progestin actions, can interact with $\mathrm{mPR} \alpha$ suggests an alternative mechanism by which this neurosteroid could potentially exert neuroprotective effects in the brain. Initial experiments on potential protective effects of allopregnanolone on cell death and apoptosis through mPRs in neuronal cells have been conducted with a mouse $\mathrm{GnRH}$-secreting neuronal cell line (GT1-7 cells) in which mPR receptor binding and signaling have been partially characterized [58]. The nuclear PR cannot be detected in GT1-7 cells, whereas there is significant expression of $\mathrm{mPR} \alpha$ and $\mathrm{mPR} \beta$ mRNAs and proteins [58]. RT-PCR shows that $\mathrm{mPR} \alpha$ mRNA is abundantly expressed in GT1-7 cells, with a lesser amount of $\mathrm{mPR} \beta$, and relatively low expression of $\mathrm{mPR} \delta$ and $\mathrm{mPR} \varepsilon$ mRNAs (fig. 1a). Progesterone activates an inhibitory $G$ protein $\left(\mathrm{G}_{\mathrm{i}}\right)$ in these cells resulting in downregulation of cAMP, which was abrogated after treatment of the cells with mPR $\alpha$ siRNA, indicating this cAMP response is mediated through $\mathrm{mPR} \alpha$ [58]. Therefore, to investigate whether allopregnanolone acts as an $\mathrm{MPR}$ agonist, mimicking the actions of progesterone, we investigated its ability to downregulate adenylyl cyclase activity.

Treatment of serum-starved GT1-7 cells with allopregnanolone for 15 min mimicked the inhibitory effects of progesterone on cAMP levels, significantly decreasing cAMP production at low concentrations of $20 \mathrm{nM}$ and 100 $\mathrm{nM}$ (fig. 1b). Allopregnanolone also mimicked the inhibitory effects of progesterone on serum starvation-induced cell death and apoptosis (fig. 1c, d). Interestingly, allopregnanolone exerted inhibitory effects on cell death and apoptosis at low physiological concentrations of 100 and $20 \mathrm{nM}$, respectively, whereas modulatory effects of the 


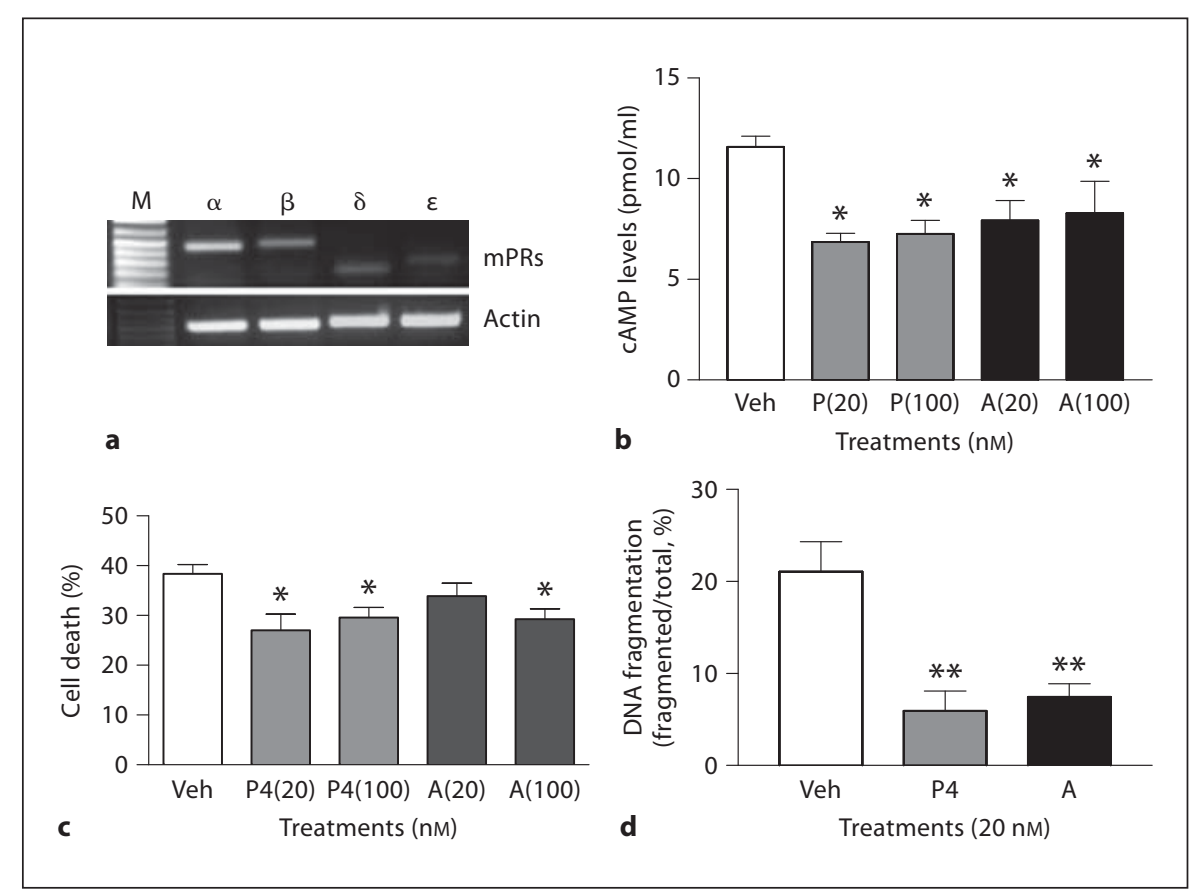

Fig. 1. The mPRs are expressed in mouse neuronal GT1-7 cells (a), and low nanomolar concentrations of allopregnanolone mimic the inhibitory effects of progesterone on cAMP production (b), cell death (c) and DNA fragmentation (d) in neuronal GT1-7 cells. a Detection of $\mathrm{mPR} \alpha, \mathrm{mPR} \beta, \mathrm{mPR} \delta$ and $\mathrm{mPR} \varepsilon$ mRNAs by RTPCR. b Cultured mouse neuronal GT1-7 cells were incubated overnight in serum-free media to reduce background adenylyl cyclase activity before treatment for $15 \mathrm{~min}$ with vehicle, progesterone or allopregnanolone (20 and $100 \mathrm{nM}$ ). The cAMP concentra-

neurosteroid on $\mathrm{GABA}_{\mathrm{A}}$ receptor functions are usually observed at $\mu \mathrm{M}$ concentrations $[20,59]$. These protective actions of allopregnanolone are likely mediated through the most abundant mPR subtype in GT1-7 cells, $\mathrm{mPR} \alpha$, and by activation of MAP kinase and Akt, as observed previously in teleost granulosa cells and in PR-negative human breast cancer cells $[12,45]$. The mPRs could potentially exert neuroprotective effects throughout the central nervous system because they are widely distributed in the brain and spinal cord [27, 34, 37]. For example, the rat cortex, where progesterone has been shown to exert maximal protective effects through MAP kinase and PI3-kinase pathways [60], shows high expression of $m P R \alpha$ and $m P R \beta$ [35]. All five members of the mPR subfamily of PAQRs (class II PAQRs) have been identified in human brains, including a brain-specific homolog, $\mathrm{mPR} \delta$ (PAQR6 [34]). Therefore, it is also important to investigate the interactions of progesterone, allopregnanolone and other neurosteroids with $\mathrm{mPR} \delta$ and the other $\mathrm{mPRs}$ tions in cell lysates were measured with an EIA kit (Cayman, Ann Arbor, Mich., USA). c, d Cells, 70\% confluent, were cultured for 4 days in serum-free media alone (vehicle) of media containing progesterone or allopreganolone. Approximately 500 cells were counted for cell death and DNA fragmentation after staining with trypan blue and by TUNEL assay, respectively, as described previously [45]. Veh: Vehicle; P4: progesterone; A: allopregnanolone. $\mathrm{n}=6 .{ }^{*} \mathrm{p}<0.05 ;{ }^{* *} \mathrm{p}<0.001$ compared to vehicle controls (oneway ANOVA and Tukey's).

$(\beta, \gamma, \varepsilon)$. In conclusion, these preliminary results suggest a potential involvement of mPRs in the antiapoptotic effects of allopregnanolone in the central nervous system.

\section{Potential Role of mPRs in Negative Feedback of Progesterone on Gonadotropin-Releasing Hormone Secretion}

Progesterone and neurosteroids influence a wide variety of brain functions including sexual behavior, neuroendocrine function and intracellular second messenger signaling $[6,10,61]$. Studies using the specific PR antagonists RU486 and PRKO mice have clearly implicated the nuclear PRs, PR-A or PR-B, in genomic progesterone actions on LH surges and facilitatory effects on female sexual behavior [62-64], as well as negative feedback progesterone effects on $\mathrm{GnRH}$ pulsatile secretion in sheep and rats $[65,66]$. However, many neural effects of proges- 
terone are too rapid to be mediated by a genomic mechanism [10, 67-70]. The teleost progestin, 17, 20ß, 21-trihydroxy-4-pregnen-3-one (20 $\beta$-S) decreases GnRH secretion from Atlantic croaker hypothalamic tissue in vitro to $20 \%$ that of controls within the initial 10 -min incubation period [61]. Some of these rapid progesterone actions in the brain could be mediated by the PR because the receptor has been shown to induce rapid extranuclear progesterone signaling through activation of Src tyrosine kinase $[18,19]$. However, other progesterone and neurosteroid actions do not appear to be mediated through PRs. For example, RU486 failed to prevent potentiation of $\mathrm{LH}$ secretory responses to multiple $\mathrm{GnRH}$ pulses in rats [71], and rapid allopregnanolone effects on lordosis persist in PRKO mice [11]. Allopregnanolone can influence $\mathrm{GnRH}$ secretion and other neural functions through modulation of $\mathrm{GABA}_{\mathrm{A}}$ receptor activity $[21,72,73]$, but can also activate mPRs as shown in figure 1. The mPRs and PGRMC1 are expressed in the hypothalamus and other brain regions controlling reproductive functions and therefore are candidates for the intermediaries of some rapid progestin actions on reproductive behavior and neuroendocrine functions $[27,34,35,58]$.

Recently, progesterone injections that resulted in high physiological levels of the hormone, such as those observed during pregnancy and the proestrus progesterone surge, were found to acutely suppress in vivo LH secretion in both wild-type and PRKO ovariectomized mice [58]. This PR-independent progesterone action is exerted at the hypothalamus and specific for this steroid since injections with the same dose of dexamethasone $(400 \mu \mathrm{g} / \mathrm{ml})$ were ineffective. A low dose of allopregnanolone $(15 \mu \mathrm{g} /$ $\mathrm{ml}$ ) also did not suppress LH secretion [58], but injections with higher amounts of the neurosteroid were not tested, so it is unclear whether allopregnanolone can mimic these progesterone effects.

Superfusion of GT1-7 cells, which express negligible amounts of PR, with progesterone caused a rapid downregulation of $\mathrm{GnRH}$ secretion. This rapid progesterone action was associated with a decrease in cAMP concentration in GT1-7 cells which was attenuated by pretreatment with pertussis toxin, a blocker of $G_{i}$ activation. A subsequent experiment demonstrated progesterone treatment caused $\mathrm{G}$ protein activation as assessed by an increase in $\left[{ }^{35} \mathrm{~S}\right]$-GTP $\gamma \mathrm{S}$ cell membrane binding which was immunoprecipitated with a $G_{i} \alpha$-subunit antibody, confirming that progesterone activates a $\mathrm{G}_{\mathrm{i}}$ in GT1-7 cells [58]. The finding that the progesterone inhibition of cAMP accumulation in these cells was not mimicked by the selective PR agonist, $\mathrm{R} 5020$, indicates this action is independent of the PR. Ear- lier studies had shown that progesterone and other progestins activate pertussis-sensitive $G_{i}$ through $m P R \alpha$ and $\mathrm{mPR} \beta$ in a wide variety of cell types including fish oocytes, human myometrial cells, human lymphocytes and human breast cancer cells [15, 17, 28, 74]. Sleiter et al. [58] showed that $\mathrm{mPR} \alpha$ and $\mathrm{mPR} \beta$ proteins are expressed in GT1-7 cells and localized to the plasma membranes where highaffinity, specific $\left[{ }^{3} \mathrm{H}\right]$-progesterone binding was detected that was not displaced with $10^{-6} \mathrm{M}$ R5020, which is characteristic of mPRs. Finally, it was demonstrated that transfection of $\mathrm{mPR} \alpha$ siRNA into GT1-7 cells decreased membrane $\left[{ }^{3} \mathrm{H}\right]$-progesterone binding and attenuated the inhibitory effect of progesterone on cAMP accumulation. Taken together, these results indicate $\mathrm{mPR} \alpha$ is a potential intermediary in these rapid negative feedback effects of progesterone on GnRH pulsatility. However, direct evidence for this role for $\mathrm{mPR} \alpha$ such as the demonstration that this action in superfused GT1-7 cells is abolished after transfection with $\mathrm{mPR} \alpha$ siRNA has not been obtained due to technical limitations. Therefore, the identity of the progesterone receptor mediating this effect of high progesterone concentrations on $\mathrm{GnRH}$ secretion remains unclear. An alternative approach, the use of a specific mPR agonist such as Org OD 02-0, would overcome the problems of using siRNA on GT1-7 cells, and would provide a clear indication of whether $\mathrm{mPR} \alpha$ has a role in this neuroendocrine control mechanism.

\section{Potential Role of mPRs in Sphingolipid Signaling}

Recent bioinformatic studies on the sequence similarities of PAQRs with alkaline ceramidases and other 7-transmembrane proteins suggest they belong to a large diverse family of distantly-related putative transmembrane hydrolases which has been named CREST (alkaline ceramidase, PAQR, Per1, SID-1 and TMEM8) [40, 75]. Alkaline ceramidases catalyze the deacylation of ceramides to yield sphingoid bases, which function as lipid second messengers. On the basis of their finding that the fungal PAQR, Izh2p, has a possible ceramidase function, Lyons and coworkers [76] proposed that PAQRs can act as ligand-activated alkaline ceramidases. Using a heterologous yeast expression system and an endogenous PAQR (Izh2p) driven reporter, these researchers showed that both an alkaline ceramidase inhibitor and supraphysiological concentrations of a homolog of adiponectin, tumor necrosis factor $\alpha(\mathrm{TNF} \alpha)$, inhibited signaling through recombinant human adiponectin receptors and $\mathrm{mPR} \beta, \mathrm{mPR} \gamma$ and $\mathrm{mPR} \delta$, but not through $\mathrm{mPR} \alpha$ or 


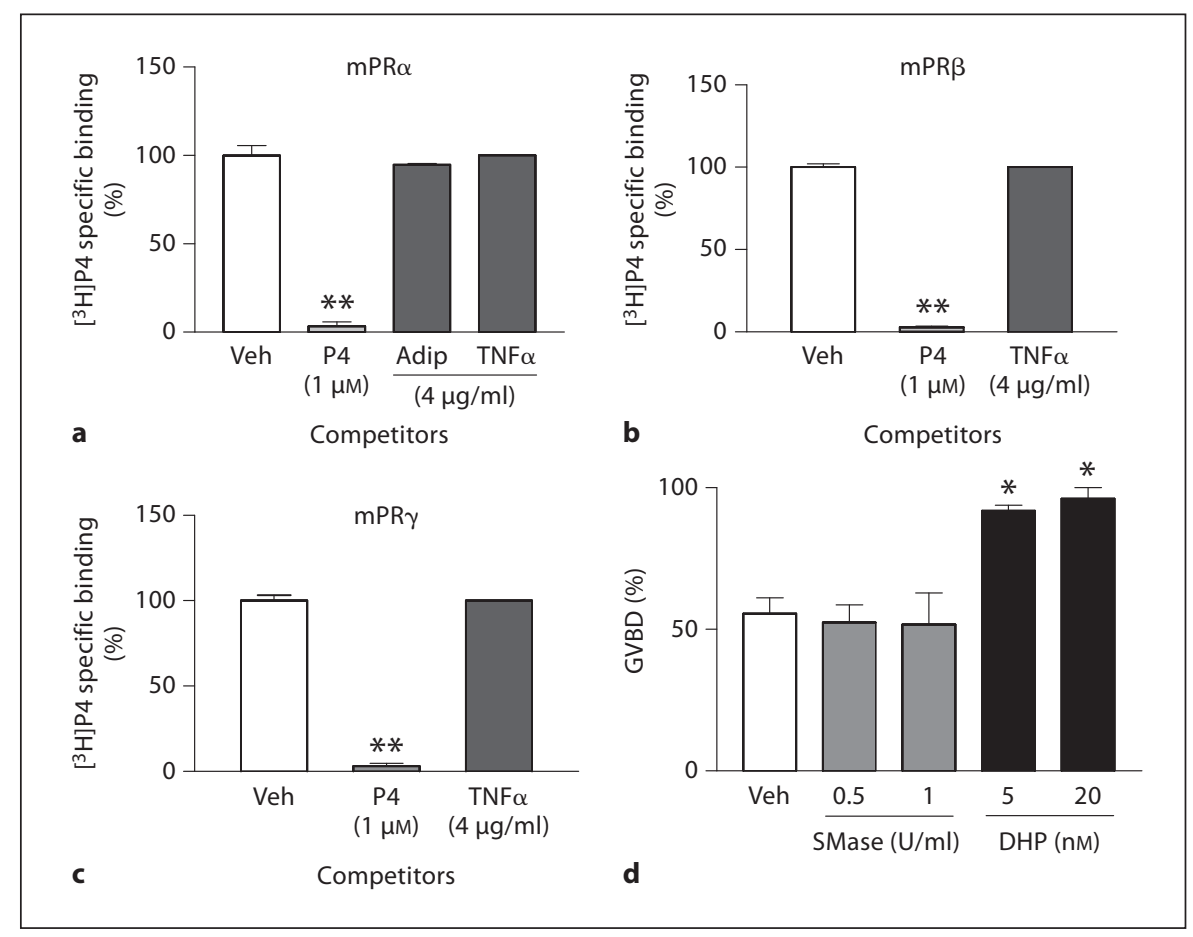

Fig. 2. The proposed role of $\mathrm{mPRs}$ in sphingolipid signaling is not supported by empirical data showing a lack of TNF $\alpha$ binding to mPRs (a-c) and the ineffectiveness of exogenous neutral sphingomyelinase in inducing meiotic maturation of zebrafish oocytes (d). a-c Single point competition with $1 \mu \mathrm{M}$ progesterone (P4), $4 \mu \mathrm{g} / \mathrm{ml} \mathrm{TNF} \alpha$ or $4 \mu \mathrm{g} / \mathrm{ml}$ adiponectin (adip) for $\left[{ }^{3} \mathrm{H}\right]$-progesterone binding to plasma membranes of MDA-MB-231 breast cancer cells over expressing $\operatorname{mPR} \alpha(\mathbf{a}), \operatorname{mPR} \beta$ (b) or $\mathrm{mPR} \gamma(\mathbf{c})$. Data represent mean percent specific $\left[{ }^{3} \mathrm{H}\right]-\mathrm{P} 4$ binding \pm SEM, $\mathrm{n}=3$. ** $\mathrm{p}<0.0001$ compared with vehicle (veh) control by one-way ANOVA and Dunnett's multiple comparison test. d Comparison of the effects of exogenous B. cerus spingomyelinase (SMase, 0.5 and $1.0 \mathrm{U} / \mathrm{ml}$ ) and 17,20 $\beta$-dihydroxy-4-pregene-3-one (DHP, 20 and $50 \mathrm{nM}$ ) on percent GVBD of denuded zebrafish oocytes. Large, fully grown zebrafish oocytes (diameter $>550 \mu \mathrm{m}$ ) were denuded and the oocytes (30-40 oocytes/ $1 \mathrm{ml}$ Leibovitz L-15 medium/well, 4 wells/treatment) were incubated with the various treatments for $3 \mathrm{~h}$ and scored at the end of the incubation period for GVBD as described previously [91]. Data represent mean percent oocytes completing GVBD \pm SEM, $n=4$. * $\mathrm{p}<0.05$ compared with vehicle control by one-way ANOVA and Dunnett's multiple comparison test.
$\mathrm{mPR} \varepsilon$ [77]. They concluded that TNF $\alpha$ is a PAQR antagonist and does not act downstream of the recombinant human receptors because signaling through Izh2p in this reporter system was unaffected by TNF $\alpha$ [77]. However, the relevance of these results obtained in a heterologous yeast system which does not encode mPRs, TNF $\alpha$ members or TNF $\alpha$ receptors to vertebrate physiology remains unclear. It is essential to obtain empirical evidence confirming this action of $\mathrm{TNF} \alpha$ in vertebrate cells before proposing $\mathrm{mPRs}$ can function as alkaline ceramidases. Therefore, we examined the potential of a high concentration of TNF $\alpha(4 \mu \mathrm{g} / \mathrm{ml}, 240 \mathrm{nM})$ to antagonize progesterone actions through mPRs by assessing its ability to compete for specific $\left[{ }^{3} \mathrm{H}\right]$-progesterone binding to the receptors overexpressed on the plasma membranes of a nuclear PR-negative human breast cancer cell line, MDA-
MB-231 cells. TNF $\alpha$ failed to compete for $\left[{ }^{3} \mathrm{H}\right]$-progesterone binding to $\mathrm{mPR} \alpha$, in agreement with the results in the yeast expression system, and its homolog, adiponectin, was also an ineffective competitor of progesterone binding (fig. 2a). However, in contrast to the findings in the yeast system, TNF $\alpha$ also did not display any potential antagonism of progesterone activity through $\mathrm{mPR} \beta$ and mPR $\gamma$ because it did not displace specific $\left[{ }^{3} \mathrm{H}\right]$-progesterone binding to these receptors (fig. $2 b, c)$. Thus, the results of the competitive binding assays in human cells do not support the suggestion that TNF $\alpha$ is an antagonist or inverse agonist of progesterone actions through mPRs at the receptor level, at least not via a conventional mechanism by interfering with ligand binding.

TNF $\alpha$ and a variety of other factors can induce the production of sphingolipids such as ceramide through several 
pathways, including the hydrolysis of sphingomyelin by sphingomyelinases (SMases) [78]. Moussatche and Lyons [40] have recently discussed evidence supporting an involvement of sphingolipids in nongenomic signaling through mPRs. These authors point out that ceramide and exogenous SMase can mimic the actions of progesterone in inducing maturation of amphibian oocytes in vitro [7981]. However, seasonal differences in the sensitivity of frog oocytes to induction of meiosis by progesterone and ceramide as well as different effects of them on membrane microdomain integrity in toad oocytes have been observed $[79,81,82]$. Moreover, the importance of $\mathrm{mPRs}$ in mediating the nongenomic action of progesterone to induce of oocyte meiotic maturation in amphibians remains unclear because nuclear PRs or PR-like forms have also been implicated $[83,84]$. In contrast, extensive evidence has been obtained that $\mathrm{mPR}$ are the primary intermediaries in progestin induction of oocyte maturation in teleosts [5]. The demonstration that microinjection of antisense oligonucleotides to $\mathrm{mPR} \alpha$ into zebrafish and goldfish oocytes blocks progestin-induced oocyte maturation in these species $[15,33]$ provides the clearest evidence to date of a specific function of mPRs in any vertebrate model. Previous studies have shown that treatment of denuded Xenopus (X. laevis), frog (R.pipiens) or toad (R. arenarum) oocytes with $0.25-1.0$ units $/ \mathrm{ml}$ neutral SMase induces germinal vesicle breakdown $(\mathrm{GVBD})$ with a similar time course to that of progesterone $[79,81,82]$. Therefore, we investigated the effects of neutral SMase in the well-characterized teleost mPR model of progestin induction of oocyte maturation. Removal of the ovarian follicle layers surrounding zebrafish oocytes results in spontaneous meiotic maturation (GVBD) which is significantly increased in the presence of 17,20ß-dihydroxy-4-pregene-3-one (DHP), the maturation inducing steroid in this species (fig. 2d; [5]). The percent of zebrafish oocytes completing GVBD after treatment with 0.5 and $1.0 \mathrm{U} / \mathrm{ml}$ Bacillus cereus neutral SMase was not significantly different from that in the vehiclecontrol group, which suggests $\mathrm{mPR}$ signaling to induce oocyte maturation does not involve sphingolipids (fig. $2 \mathrm{~d}$ ). To the best of our knowledge there are no reports of stimulatory effects of SMase or ceramide on oocyte meiotic maturation in any teleost species amongst the extensive literature on hormonal regulation of this process in fish. The absence of any evidence for an involvement of sphingolipid signaling in $\mathrm{mPR}$ induction of oocyte maturation in teleosts suggests that it is not an intrinsic characteristic of $\mathrm{mPRs}$ in homologous vertebrate cell models.

Finally, the role of mPRs in mediating the antiapoptotic effects of progestins in croaker granulosa and hu- man breast cancer cells is inconsistent with their involvement in sphingolipid signaling because SMases and ceramide have been shown to be primary mediators of an opposite effect, apoptosis, in a wide range of tissues and cell types, including granulosa and neuronal cells [8587]. For example, ceramide suppresses prosurvival signaling pathways such as Akt [88]. SMases induce ceramide and cytokine production after ischemia and neurons lacking the enzyme have increased survival and decreased vulnerability to ischemia [89]. In addition, SMase inhibitors have proven useful for treatment of neuronal apoptosis [90]. It is concluded that the evidence obtained to date in vertebrate cell models does not support the suggestion that mPRs are alkaline ceramidases involved in sphingolipid signaling. However, the ability of other vertebrate PAQRs such as the adiponectin receptors to have this function has not been extensively investigated and remains a possibility.

\section{Concluding Remarks}

Recent studies showing that mPRs are widely expressed in the central nervous system and that one $\mathrm{mPR}$ isoform, $\mathrm{mPR} \delta$ (PAQR6), is exclusively expressed in the brain suggests that $\mathrm{mPR}$ are likely intermediates in a variety of nonclassical progesterone actions in neural tissues. The finding that allopregnanolone can act as an $\mathrm{mPR}$ agonist at low physiologically relevant concentrations indicates an additional receptor mechanism by which neurosteroids can potentially modulate neural functions. Our preliminary results in GT1-7 cells suggesting that neuroprotective effects of progesterone and allopreganolone are partially mediated through mPRs need to be confirmed in additional neuronal models. The receptors are also potential intermediaries in progesterone modulation of GnRH secretion under certain conditions, but direct evidence is lacking. More comprehensive studies using a combination of in vivo and in vitro models, additional experimental approaches such as the use of specific mPR agonists and siRNA technology, and investigations of additional targets such as $\mathrm{MPR} \delta$ will be required to obtain a clearer understanding of the physiological functions of mPRs in the brain.

\section{Ackowledgement}

Research on mPRs conducted by Thomas and coworkers was funded by Grant ESO ESO12961 to P.T. from the National Institutes of Health. 


\section{References}

$>1$ Mulac-Jericevic B, Conneely OM: Reproduc- $>14$ Zuo L, Li W, You S: Progesterone reverses the tive tissue selective actions of progesterone receptors. Reproduction 2004;128:139-146.

2 Revelli A, Massobrio M, Tesarik J: Nongenomic actions of steroid hormones in reproductive tissues. Endocrine Rev 1998;19:3-17.

$>3$ Watson CS, Gametchu B: Membrane-initiated steroid actions and the proteins that mediate them. Proc Soc Exp Biol Med 1999;220: 9-19.

$\checkmark 4$ Norman AW, Mizwicki MT, Norman DP: Steroid-hormone rapid actions, membrane receptors and a conformational ensemble model. Nat Rev Drug Discov 2004;3:27-41.

5 Thomas P: Rapid steroid hormone actions initiated at the cell surface and the receptors that mediate them with an emphasis on recent progress in fish models. Gen Comp Endocrinol 2012;175:367-383.

$\checkmark 6$ Ke FC, Ramirez VD: Membrane mechanism mediates progesterone stimulatory effect on LHRH release from superfused rat hypothalami in vitro. Neuroendocrinology 1987; 45:514-517.

7 Tubbs C, Thomas P: Progestin signaling through an olfactory $G$ protein and membrane progestin receptor-alpha in Atlantic croaker sperm: potential role in induction of sperm hypermotility. Endocrinology 2009; 150:473-484.

$>8$ Mani SK, Blaustein JD: Neural progestin receptors and female sexual behavior. Neuroendocrinology 2012;96:152-161.

$>9$ Chien EJ, Chang CP, Lee WF, Su TH, Wu CH: Non-genomic immunosuppressive actions of progesterone inhibits PHA-induced alkalinization and activation in $\mathrm{T}$ cells. J Cell Biochem 2006;99:292-304.

$>10$ DeBold JF, Frye CA: Genomic and non-genomic actions of progesterone in the control of female hamster sexual behavior. Horm Behav 1994;28:445-453.

$\checkmark 11$ Frye CA, Sumida K, Lydon JP, O’Malley BW, Pfaff DW: Mid-aged and aged wild-type and progestin receptor knockout (PRKO) mice demonstrate rapid progesterone and 3alpha,5alpha-THP-facilitated lordosis. Psychopharmacology (Berl) 2006;185:423-432.

- 12 Dressing GE, Alyea R, Pang Y, Thomas P: Membrane progesterone receptors (mPRs) mediate progestin induced antimorbidity in breast cancer cells and are expressed in human breast tumors. Horm Cancer 2012;3: 101-112.

13 Peluso JJ, Pappalardo A, Losel R, Wehling M: Progesterone membrane receptor component 1 expression in the immature rat ovary and its role in mediating progesterone's antiapoptotic action. Endocrinology 2006;147: $3133-3140$. mesenchymal phenotypes of basal phenotype breast cancer cells via a membrane progesterone receptor mediated pathway. Breast Cancer Res 2010;12:R34.

15 Zhu Y, Rice CD, Pang Y, Pace M, Thomas P: Cloning, expression, and characterization of a membrane progestin receptor and evidence it is an intermediary in meiotic maturation of fish oocytes. Proc Natl Acad Sci USA 2003; 100:2231-2236.

16 Charles NJ, Thomas P, Lange CA: Expression of membrane progesterone receptors ( $\mathrm{mPR}$ / PAQR) in ovarian cancer cells: implications for progesterone-induced signaling events. Horm Cancer 2010;1:167-176.

17 Karteris E, Zervou S, Pang Y, Dong J, Hillhouse EW, Randeva HS, Thomas P: Progesterone signaling in human myometrium through two novel membrane G proteincoupled receptors: potential role in functional progesterone withdrawal at term. Mol Endocrinol 2006;20:1519-1534.

18 Mani S: Progestin receptor subtypes in the brain: the known and the unknown. Endocrinology 2008;149:2750-2756.

19 Boonyaratanakornkit V, Scott MP, Ribon V, Sherman L, Anderson SM, Maller JL, Miller WT, Edwards DP: Progesterone receptor contains a proline-rich motif that directly interacts with $\mathrm{SH} 3$ domains and activates cSrc family tyrosine kinases. Mol Cell 2001;8: 269-280

20 Bracamontes J, McCollum M, Esch C, Li P, Ann J, Steinbach JH, Akk G: Occupation of either site for the neurosteroid allopregnanolone potentiates the opening of the $\mathrm{GABA}_{\mathrm{A}}$ receptor induced from either transmitter binding site. Mol Pharmacol 2011;80:79-86.

21 Calogero AE, Palumbo MA, Bosboom AM, Burrello N, Ferrara E, Palumbo G, Petraglia F, D'Agata R: The neuroactive steroid allopregnanolone suppresses hypothalamic gonadotropin-releasing hormone release through a mechanism mediated by the gamma-aminobutyric acidA receptor. J Endocrinol 1998;158:121-125.

-22 Losel RM, Besong D, Peluso JJ, Wehling M: Progesterone receptor membrane component 1 - many tasks for a versatile protein. Steroids 2008;73:929-934.

23 Rohe HJ, Ahmed IS, Twist KE, Craven RJ: PGRMC1 (progesterone receptor membrane component 1): a targetable protein with multiple functions in steroid signaling, P450 activation and drug binding. Pharmacol Ther 2009;121:14-19.

24 Xu J, Zeng C, Chu W, Pan F, Rothfuss JM, Zhang F, Tu Z, Zhou D, Zeng D, Vangveravong S, Johnston F, Spitzer D, Chang KC, Hotchkiss RS, Hawkins WG, Wheeler KT, Mach RH: Identification of the PGRMC1 protein complex as the putative sigma-2 receptor binding site. Nat Commun 2011;2: 380 .
25 Thomas P: Characteristics of membrane progesterone receptor alpha $(\mathrm{mPR} \alpha)$ and progesterone membrane component 1 (PGRMC1) and their roles in mediating rapid steroid actions. Front Neuroendocrinol 2008;29:292-312.

26 Cahill MA: Progesterone receptor membrane component 1: an integrative review. J Steroid Biochem Mol Biol 2007;105:16-36.

27 Zhu Y, Bond J, Thomas P: Identification, classification, and partial characterization of genes in humans and other vertebrates homologous to a fish membrane progestin receptor. Proc Natl Acad Sci USA 2003;100: 2237-2242.

28 Thomas P, Pang Y, Dong J, Groenen P, Kelder J, de Vlieg J, Zhu Y, Tubbs C: Steroid and G protein binding characteristics of the seatrout and human progestin membrane receptor alpha subtypes and their evolutionary origins. Endocrinology 2007;148:705-718.

29 Smith JL, Kupchak BR, Garitaonandia I, Hoang LK, Maina AS, Regalla LM, Lyons TJ: Heterologous expression of human mPRalpha, mPRbeta and mPRgamma in yeast confirms their ability to function as membrane progesterone receptors. Steroids 2008;73:1160-1173.

30 Ashley RL, Clay CM, Farmerie TA, Niswender GD, Nett TM: Cloning and characterization of an ovine intracellular seven transmembrane receptor for progesterone that mediates calcium mobilization. Endocrinology 2006;147:4151-4159.

31 Josefsberg Ben-Yehoshua L, Lewellyn AL, Thomas P, Maller JL: The role of Xenopus membrane progesterone receptor beta in mediating the effect of progesterone on oocyte maturation. Mol Endocrinol 2007;21: 664-673.

32 Hanna R, Pang Y, Thomas P, Zhu Y: Cellsurface expression, progestin binding, and rapid nongenomic signaling of zebrafish membrane progestin receptors alpha and beta in transfected cells. J Endocrinol 2006; 190:247-260.

33 Tokumoto M, Nagahama Y, Thomas P, Tokumoto T: Cloning and identification of a membrane progestin receptor in goldfish ovaries and evidence it is an intermediary in oocyte meiotic maturation. Gen Comp Endocrinol 2006;145:101-108.

34 Tang YT, Hu T, Arterburn M, Boyle B, Bright JM, Emtage PC, Funk WD: PAQR proteins: a novel membrane receptor family defined by an ancient 7-transmembrane pass motif. J Mol Evol 2005;61:372-380.

35 Intlekofer KA, Petersen SL: Distribution of mRNAs encoding classical progestin receptor, progesterone membrane components 1 and 2 , serpine $\mathrm{mRNA}$ binding protein 1 , and progestin and ADIPOQ receptor family members 7 and 8 in rat forebrain. Neuroscience $2011 ; 172: 55-65$. 
-36 Foster H, Reynolds A, Stenbeck G, Dong J, Thomas P, Karteris E: Internalisation of membrane progesterone receptor-alpha after treatment with progesterone: potential involvement of a clathrin-dependent pathway. Mol Med Report 2010;3:27-35.

- 37 Labombarda F, Meffre D, Delespierre B, Krivokapic-Blondiaux S, Chastre A, Thomas P, Pang Y, Lydon JP, Gonzalez SL, De Nicola AF, Schumacher M, Guennoun R: Membrane progesterone receptors localization in the mouse spinal cord. Neuroscience 2010; 166:94-106.

38 Thomas P, Tubbs C, Garry VF: Progestin functions in vertebrate gametes mediated by membrane progestin receptors (mPRs): identification of $\mathrm{mPR} \alpha$ on human sperm and its association with sperm motility. Steroids 2009;74:614-621.

- 39 Zhu Y, Hanna RN, Schaaf MJ, Spaink HP, Thomas P: Candidates for membrane progestin receptors - past approaches and future challenges. Comp Biochem Physiol C Toxicol Pharmacol 2008;148:381-389.

40 Moussatche P, Lyons TJ: Non-genomic progesterone signalling and its non-canonical receptor. Biochem Soc Trans 2012;40:200204.

-41 Telleria CM, Stocco CO, Stati AO, Deis RP: Progesterone receptor is not required for progesterone action in the rat corpus luteum of pregnancy. Steroids 1999;64:760-766. 42 Chaffin CL, Stouffer RL: Role of gonadotro-
phins and progesterone in the regulation of morphological remodelling and atresia in the monkey peri-ovulatory follicle. Hum Reprod 2000;15:2489-2495.

-43 Peluso JJ, Pappalardo A: Progesterone regulates granulosa cell viability through a protein kinase G-dependent mechanism that may involve 14-3-3sigma. Biol Reprod 2004; 71:1870-1878.

-44 Rae MT, Menzies GS, Bramley TA: Bovine ovarian non-genomic progesterone binding sites: presence in follicular and luteal cell membranes. J Endocrinol 1998;159:413-427.

-45 Dressing GE, Pang Y, Dong J, Thomas P: Progestin signaling through $\mathrm{mPR} \alpha$ in Atlantic croaker granulosa/theca cell cocultures and its involvement in progestin inhibition of apoptosis. Endocrinology 2010;151:59165926.

46 Peluso JJ, Pappalardo A, Losel R, Wehling M: Expression and function of PAIRBP1 within gonadotropin-primed immature rat ovaries: PAIRBP1 regulation of granulosa and luteal cell viability. Biol Reprod 2005;73:261-270.

-47 Peluso JJ, Romak J, Liu X: Progesterone receptor membrane component-1 (PGRMC1) is the mediator of progesterone's antiapoptotic action in spontaneously immortalized granulosa cells as revealed by PGRMC1 small interfering ribonucleic acid treatment and functional analysis of PGRMC1 mutations. Endocrinology 2008;149:534-543.
48 Peluso JJ, Liu X, Gawkowska A, Lodde V, Wu CA: Progesterone inhibits apoptosis in part by PGRMC1-regulated gene expression. Mol Cell Endocrinol 2010;320:153-161.

49 Kelder J, Azevedo R, Pang Y, de Vlieg J, Dong J, Thomas P: Comparison between steroid binding to membrane progesterone receptor alpha (mPRalpha) and to nuclear progesterone receptor: correlation with physicochemical properties assessed by comparative molecular field analysis and identification of mPRalpha-specific agonists. Steroids 2010; 75:314-322.

50 Song G, Ouyang G, Bao S: The activation of Akt/PKB signaling pathway and cell survival. J Cell Mol Med 2005;9:59-71.

51 Lin H, Chen C, Li X, Chen BD: Activation of the MEK/MAPK pathway is involved in bryostatin1-induced monocytic differentiation and up-regulation of X-linked inhibitor of apoptosis protein. Exp Cell Res 2002;272: 192-198.

52 She QB, Solit DB, Ye Q, O’Reilly KE, Lobo J, Rosen N: The BAD protein integrates survival signaling by EGFR/MAPK and PI3K/ Akt kinase pathways in PTEN-deficient tumor cells. Cancer Cell 2005;8:287-297.

53 Datta SR, Dudek H, Tao X, Masters S, Fu H, Gotoh Y, Greenberg ME: Akt phosphorylation of BAD couples survival signals to the cell-intrinsic death machinery. Cell 1997;91: 231-241.

54 Charalampopoulos I, Remboutsika E, Margioris AN, Gravanis A: Neurosteroids as modulators of neurogenesis and neuronal survival. Trends Endocrinol Metab 2008; 19: 300-307.

55 Birzniece V, Backstrom T, Johansson IM, Lindblad C, Lundgren P, Lofgren M, Olsson T, Ragagnin G, Taube M, Turkmen S, Wahlstrom G, Wang MD, Wihlback AC, Zhu D: Neuroactive steroid effects on cognitive functions with a focus on the serotonin and GABA systems. Brain Res Rev 2006;51:212239.

56 Borowicz KK, Piskaorska B, Banach M, Czuczwar SJ: Neuroprotective actions of neurosteroids. Front Endocrinol 2011;2:50.

57 Rupprecht R, Reul JM, Trapp T, van Steensel B, Wetzel C, Damm K, Zieglgansberger W, Holsboer F: Progesterone receptor-mediated effects of neuroactive steroids. Neuron 1993; 11:523-530.

58 Sleiter N, Pang Y, Park C, Horton TH, Dong J, Thomas P, Levine JE: Progesterone receptor A (PRA) and PRB-independent effects of progesterone on gonadotropin-releasing hormone release. Endocrinology 2009;150: 3833-3844.

59 Earl DE, Tietz EI: Inhibition of recombinant L-type voltage-gated calcium channels by positive allosteric modulators of GABAA receptors. J Pharmacol Exp Ther 2011;337:301311.
60 Kaur P, Jodhka PK, Underwood WA, Bowles CA, de Fiebre NC, de Fiebre CM, Singh M: Progesterone increases brain-derived neuroptrophic factor expression and protects against glutamate toxicity in a mitogen-activated protein kinase- and phosphoinositide-3 kinase-dependent manner in cerebral cortical explants. J Neurosci Res 2007;85: 2441-2449.

61 Thomas P, Pang Y, Zhu Y, Detweiler C, Doughty K: Multiple rapid progestin actions and progestin membrane receptor subtypes in fish. Steroids 2004;69:567-573.

62 Mani SK, Allen JM, Lydon JP, Mulac-Jericevic B, Blaustein JD, DeMayo FJ, Conneely O, O'Malley BW: Dopamine requires the unoccupied progesterone receptor to induce sexual behavior in mice. Mol Endocrinol 1996; 10:1728-1737.

63 White MM, Sheffer I, Teeter J, Apostolakis EM: Hypothalamic progesterone receptor-A mediates gonadotropin surges, self priming and receptivity in estrogen-primed female mice. J Mol Endocrinol 2007;38:35-50.

64 Chappell PE, Schneider JS, Kim P, Xu M, Lydon JP, O’Malley BW, Levine JE: Absence of gonadotropin surges and gonadotropin-releasing hormone self-priming in ovariectomized (OVX), estrogen (E2)-treated, progesterone receptor knockout (PRKO) mice. Endocrinology 1999;140:3653-3658.

- 65 Skinner DC, Evans NP, Delaleu B, Goodman RL, Bouchard P, Caraty A: The negative feedback actions of progesterone on gonadotropin-releasing hormone secretion are transduced by the classical progesterone receptor. Proc Natl Acad Sci USA 1998;95:1097810983.

66 Smith MS, Fox SR, Chatterton RT: Role of proestrous progesterone secretion in suppressing basal pulsatile LH secretion during estrus of the estrous cycle. Neuroendocrinology 1989;50:308-314.

67 Bergfeld EG, Kojima FN, Cupp AS, Wehrman ME, Peters KE, Mariscal V, Sanchez T, Kinder JE: Changing dose of progesterone results in sudden changes in frequency of luteinizing hormone pulses and secretion of 17 beta-estradiol in bovine females. Biol Reprod 1996;54:546-553.

68 Schumacher M, Coirini H, Robert F, Guennoun R, El-Etr M: Genomic and membrane actions of progesterone: implications for reproductive physiology and behavior. Behav Brain Res 1999;105:37-52.

69 Hwang JY, Duncan RS, Madry C, Singh M, Koulen P: Progesterone potentiates calcium release through IP3 receptors by an Akt-mediated mechanism in hippocampal neurons. Cell Calcium 2009;45:233-242.

70 Balasubramanian B, Portillo W, Reyna A, Chen JZ, Moore AN, Dash PK, Mani SK: Nonclassical mechanisms of progesterone action in the brain: I. Protein kinase $\mathrm{C}$ activation in the hypothalamus of female rats. Endocrinology 2008;149:5509-5517. 
71 Turgeon JL, Waring DW: Luteinizing hormone secretion from wild-type and progesterone receptor knockout mouse anterior pituitary cells. Endocrinology 2001;142:31083115.

72 Sullivan SD, Moenter SM: GABAergic integration of progesterone and androgen feedback to gonadotropin-releasing hormone neurons. Biol Reprod 2005;72:33-41.

73 Luchetti S, Huitinga I, Swaab DF: Neurosteroid and GABA-A receptor alterations in Alzheimer's disease, Parkinson's disease and multiple sclerosis. Neuroscience 2011;191: 6-21.

74 Dosiou C, Hamilton AE, Pang Y, Overgaard MT, Tulac S, Dong J, Thomas P, Giudice LC: Expression of membrane progesterone receptors on human T lymphocytes and Jurkat cells and activation of $\mathrm{G}$-proteins by progesterone. J Endocrinol 2008;196:67-77.

75 Pei J, Millay DP, Olson EN, Grishin NV: CREST - a large and diverse superfamily of putative transmembrane hydrolases. Biol Direct 2011;6:37.

76 Villa NY, Kupchak BR, Garitaonandia I, Smith JL, Alonso E, Alford C, Cowart LA, Hannun YA, Lyons TJ: Sphingolipids function as downstream effectors of a fungal PAQR. Mol Pharmacol 2009;75:866-875.

$>77$ Kupchak BR, Garitaonandia I, Villa NY, Smith JL, Lyons TJ: Antagonism of human adiponectin receptors and their membrane progesterone receptor paralogs by TNFalpha and a ceramidase inhibitor. Biochemistry 2009;48:5504-5506.
78 Wu BX, Clarke CJ, Hannun YA: Mammalian neutral sphingomyelinases: regulation and roles in cell signaling responses. Neuromolecular Med 2010;12:320-330.

$>79$ Morrill GA, Kostellow AB: Progesterone release of lipid second messengers at the amphibian oocyte plasma membrane: role of ce ramide in initiating the $\mathrm{G} 2 / \mathrm{M}$ transition. Biochem Biophys Res Commun 1998;246: 359-363.

80 Morrill GA, Kostellow AB: Progesterone in duces meiotic division in the amphibian oocyte by releasing lipid second messengers from the plasma membrane. Steroids 1999 64:157-167.

81 Strum JC, Swenson KI, Turner JE, Bell RM: Ceramide triggers meiotic cell cycle progression in Xenopus oocytes. A potential mediator of progesterone-induced maturation. J Biol Chem 1995;270:13541-13547.

82 Buschiazzo J, Alonso TS, Biscoglio M, Antollini SS, Bonini IC: Nongenomic steroid- and ceramide-induced maturation in amphibian oocytes involves functional caveolae-like microdomains associated with a cytoskeletal environment. Biol Reprod 2011;85:808-822.

83 Bayaa M, Booth RA, Sheng Y, Liu XJ: The classical progesterone receptor mediates Xenopus oocyte maturation through a nongenomic mechanism. Proc Natl Acad Sci USA 2000;97:12607-12612.

84 Tian J, Kim S, Heilig E, Ruderman JV: Identification of XPR-1, a progesterone receptor required for Xenopus oocyte activation. Proc Natl Acad Sci USA 2000;97:14358-14363.
85 Witty JP, Bridgham JT, Johnson AL: Induction of apoptotic cell death in hen granulosa cells by ceramide. Endocrinology 1996;137: 5269-5277.

86 Pru JK, Hendry IR, Davis JS, Rueda BR: Soluble Fas ligand activates the sphingomyelin pathway and induces apoptosis in luteal steroidogenic cells independently of stress-activated p38(MAPK). Endocrinology 2002;143: 4350-4357.

87 Kilkus J, Goswami R, Testai FD, Dawson G: Ceramide in rafts (detergent-insoluble fraction) mediates cell death in neurotumor cell lines. J Neurosci Res 2003;72:65-75.

88 Zhou H, Summers SA, Birnbaum MJ, Pittman RN: Inhibition of Akt kinase by cellpermeable ceramide and its implications for ceramide-induced apoptosis. J Biol Chem 1998;273:16568-16575.

-89 Yu ZF, Nikolova-Karakashian M, Zhou D, Cheng G, Schuchman EH, Mattson MP: Pivotal role for acidic sphingomyelinase in cerebral ischemia-induced ceramide and cytokine production, and neuronal apoptosis. J Mol Neurosci 2000;15:85-97.

90 Farooqui AA, Horrocks LA, Farooqui T: Interactions between neural membrane glycerophospholipid and sphingolipid mediators: a recipe for neural cell survival or suicide. J Neurosci Res 2007;85:1834-1850.

-91 Pang Y, Thomas P: Involvement of estradiol17 beta and its membrane receptor, $G$ protein coupled receptor 30 (GPR30) in regulation of oocyte maturation in zebrafish, Danio rario. Gen Comp Endocrinol 2009;161:58-61. 